\title{
Application of Multi-Criteria Decision Analysis for Choice Geokhods Cutting Head
}

\author{
Alexei Khoreshok ${ }^{1}$, Kirill Ananyev ${ }^{1}$, Aleksandr Ermakov ${ }^{1}$, and Elena Golikova ${ }^{2}$ \\ ${ }^{1}$ T.F. Gorbachev Kuzbass State Technical University, 650000, Kemerovo, Russian Federation \\ ${ }^{2}$ Prokopyevsk branch of T.F. Gorbachev Kuzbass State Technical University, 653033, Prokopyevsk, \\ Russian Federation
}

\begin{abstract}
The article deals with the choice of cutterheads for Geokhod in the early development stages. Early development stages are characterized by the lack of quantitative characteristics, such as cutting forces, weight, feed forces, etc. In this case, the choice is made on the accordance of the cutterheads with the requirements for them. Under such conditions were determined the most appropriate method of multi-criteria analysis for the choice of the cutterheads - "ELECTRE III". The results of the use of this method are established the most fully meet the requirements cutter heads: a rotary, drum, and head with fixed heads.
\end{abstract}

\section{Introduction}

At the early development stages of the technical objects, which include the geokhod's cutterheads [1-3], it is necessary to determine the range of the more fully satisfying for requirements technical solutions from a variety of possible solutions. At this stage, there are often no quantitative characteristics of the solutions (alternatives). With a certain set of requirements to the cutterheads [4], this problem is a multi-criteria problem of choice [5] Multi-Criteria Decision Analysis (MCDA).

Nowadays there are more than 70 MCDA methods [6], which are based on different approaches to the formalization of the rational choice model [7]:

- value and utility functions;

- outranking methods;

- methods of verbal analysis, etc.

Each of these methods can be better for solving a particular task and we can't prefer one of it initially.

Thus, the objectives of the study are:

- to determine the MCDA method for the choice of the cutterheads for geokhod;

- to choose the cutting heads that the best satisfying for requirements for geokhods cutting heads. 


\section{Materials and Methods}

In [8] the MCDA method choosing by the presence of input data, while several methods can be included in one group. Method's determination by the appropriateness index (AI) for the solving task [6] allows quantifying the applicability of the method by several attributes.

The features of the MCDA methods are identified by the relevant evaluation criteria. For determining criteria, twelve questions are defined. Three questions are the filtering questions and nine questions are the scoring questions [6].

Filtering questions:

1. Is the method able to solve the problem (choice, optimization etc.)??

2. Should the method be compensatory/non-compensatory (compensate for the low value of one criterion due to the high value of another criterion)?

3. What input data is required by the method?

Scoring questions:

1. What preference information does the method need?

2. What decision rule does the method use to rank or sort the alternatives?

3. Does the method evaluate the feasibility of the alternatives?

4. Can the method handle any subjective attribute?

5. Does the method handle qualitative or quantitative data?

6 . Does the method deal with discrete or continuous data?

7. Can the method handle the problem with the hierarchy structure of attributes?

8. Is the method able to capture uncertainties existing in the problem?

9. Can the method support visual analytics?

For each scoring question are assigned a weighting factor, which can take integer values from 0 to 10 , where 0 stands for extremely unimportant while 10 represents extremely important.

The filtering questions are utilized to screen out inappropriate methods. Appropriate methods are comparing on the scoring questions. If the answer is affirmative, it means that the method is able to perform the required feature, and the method is assigned a value of one for this criteria, if not - zero.

AI of the $j$-th method is determined by Equation [6]

$$
A I_{j}=\frac{\sum_{i=1}^{n} w_{i} b_{j i}}{\sum_{i=1}^{n} w_{i}} 100 \%,
$$

where $n$ is the number of evaluation criteria used to examine the methods with respect to the

given problem, $w_{i}$ are the weighting factor of the $i$-th scoring question, $b_{j i}$ is an evaluation of the $j$-th method on the $i$-th scoring question $\left(b_{j i}=1\right.$ or 0$)$.

$\mathrm{AI}$ ranges from 0 to $100 \%$, the higher value of $\mathrm{AI}$ is better to solve a given decision problem.

At the stage of MCDA application, it is impossible to create value (utility) function because there are no quantitative indexes for comparing alternatives at this stage. In addition, there isn't a need to choose a single solution. There is a need to identify several alternatives that the best satisfying for requirements to them. Methods should be noncompensatory, that is, a disadvantage in one criterion cannot be offset by an advantage in other criteria.

Based on this, the required answers to the three filtering questions are formulated: 
1. The method is able to solve the problem of choosing several alternatives or ranking alternatives.

2. The method should be non-compensatory or partially compensatory.

3. Input data of the method is the matrix of estimations of alternatives on criteria.

Table 1 shows the results of the MCDA review, containing information on the filtering questions [5-9].

Table 1. The results of the MCDA review, containing information on the filtering questions.

\begin{tabular}{|l|c|c|c|}
\hline \multirow{2}{*}{ MCDA } & \multicolumn{3}{|c|}{ Characteristics of the method } \\
\cline { 2 - 4 } & Solving problems & $\begin{array}{c}\text { Compensatory/ } \\
\text { non-compensatory }\end{array}$ & Required input data \\
\hline MAUT & Choice, ranking & Compensatory & Value function \\
\hline ELECTRE III & Ranking & Non-compensatory & The evaluation matrix \\
\hline REGIME & Ranking & Partially compensatory & The evaluation matrix \\
\hline NAIADE & Ranking & Partially compensatory & $\begin{array}{c}\text { The evaluation matrix } \\
\text { and value function }\end{array}$ \\
\hline AHP/ANP & Choice, ranking & Compensatory & $\begin{array}{c}\text { Pairwise comparisons } \\
\text { matrix }\end{array}$ \\
\hline EVAMIX & Choice & Partially compensatory & The evaluation matrix \\
\hline PROMETHEE & Choice, ranking & Partially compensatory & The evaluation matrix \\
\hline MOP/GP & Choice & Compensatory & Value function \\
\hline MACBETH & Choice, ranking & Compensatory & The evaluation matrix \\
\hline TOPSIS & Choice, ranking & Compensatory & The evaluation matrix \\
\hline DEA & Choice, ranking & Compensatory & The evaluation matrix \\
\hline SMART & Choice & Partially compensatory & $\begin{array}{c}\text { The evaluation matrix } \\
\text { Value function }\end{array}$ \\
\hline LEXOGRAFIC & Ranking & Non-compensatory & The evaluation matrix \\
\hline
\end{tabular}

Four methods have the required answers to the filtering questions: ELECTRE III, REGIME, PROMETHEE, LEXOGRAFIC. Information about these methods is considering in table 2 .

Table 2. MCDA characteristics.

\begin{tabular}{|c|c|c|c|c|}
\hline \multirow{2}{*}{$\begin{array}{c}\text { Characteristics of } \\
\text { the method }\end{array}$} & \multicolumn{4}{|c|}{ MCDA } \\
\hline & ELECTRE III & REGIME & PROMETHEE & LEXOGRAFIC \\
\hline $\begin{array}{l}\text { Preference } \\
\text { information }\end{array}$ & $\begin{array}{l}\text { Relative criteria } \\
\text { weight, indifference, } \\
\text { preference and veto } \\
\text { thresholds, evaluation } \\
\text { of alternatives } \\
\text { according to the } \\
\text { criteria }\end{array}$ & $\begin{array}{l}\text { Ranked } \\
\text { criteria } \\
\text { weight, } \\
\text { evaluation of } \\
\text { alternatives } \\
\text { according to } \\
\text { the criteria }\end{array}$ & $\begin{array}{l}\text { Relative criteria } \\
\text { weight, } \\
\text { preference } \\
\text { thresholds, } \\
\text { evaluation of } \\
\text { alternatives } \\
\text { according to the } \\
\text { criteria }\end{array}$ & $\begin{array}{l}\text { Criteria are } \\
\text { ranked in the } \\
\text { order of their } \\
\text { importance }\end{array}$ \\
\hline Decision rule & outranking methods & $\begin{array}{l}\text { outranking } \\
\text { methods }\end{array}$ & $\begin{array}{l}\text { outranking } \\
\text { methods }\end{array}$ & $\begin{array}{c}\text { Compare by the } \\
\text { most important } \\
\text { criterion }\end{array}$ \\
\hline $\begin{array}{l}\text { Feasibility } \\
\text { evaluation }\end{array}$ & No & No & No & No \\
\hline Subjective & Yes & Yes & Yes & Yes \\
\hline $\begin{array}{c}\text { Quantitative/ } \\
\text { qualitative data }\end{array}$ & Quantitative & $\begin{array}{l}\text { Quantitative/ } \\
\text { qualitative }\end{array}$ & Quantitative & qualitative \\
\hline $\begin{array}{c}\text { Discrete/ } \\
\text { continuous data }\end{array}$ & Discrete & Discrete & $\begin{array}{l}\text { Discrete/ } \\
\text { continuous }\end{array}$ & Discrete \\
\hline
\end{tabular}


Table 3. MCDA methods comparing on the scoring questions and AI determining.

\begin{tabular}{|c|c|c|c|c|c|}
\hline \multirow{2}{*}{$\begin{array}{c}\text { Scoring } \\
\text { questions }\end{array}$} & \multirow{2}{*}{$\begin{array}{c}\text { Weighting } \\
\text { factor, } w_{i}\end{array}$} & $\begin{array}{c}\text { ELECTRE } \\
\text { III }\end{array}$ & REGIME & PROMETHEE & LEXOGRAFIC \\
\cline { 3 - 6 } & 10 & $b_{j i}$ & $b_{j i}$ & $b_{j i}$ & $b_{j i}$ \\
\hline 1 & 7 & 1 & 0 & 1 & 0 \\
\hline 2 & 6 & 1 & 1 & 1 & 0 \\
\hline 3 & 5 & 1 & 1 & 1 & 1 \\
\hline 4 & 8 & 1 & 1 & 1 & 0 \\
\hline 5 & 6 & 1 & 1 & 0 & 1 \\
\hline 6 & 3 & 0 & 0 & 0 & 0 \\
\hline 7 & 8 & 1 & 1 & 1 & 1 \\
\hline 8 & 2 & 0 & 1 & 1 & 35 \\
\hline 9 & & 91 & 76 & 84 & 0 \\
\hline
\end{tabular}

ELECTRE III has the highest value of AI. It means, that ELECTRE III method the best from ELECTRE III, REGIME, PROMETHEE, LEXOGRAFIC for the choice of the cutter heads for geokhod.

ELECTRE III (ELimination Et Choix Traduisant la Realite) is using the concept of outranking approach [6]. General structure of ELECTRE III is shown in figure 1 [7].

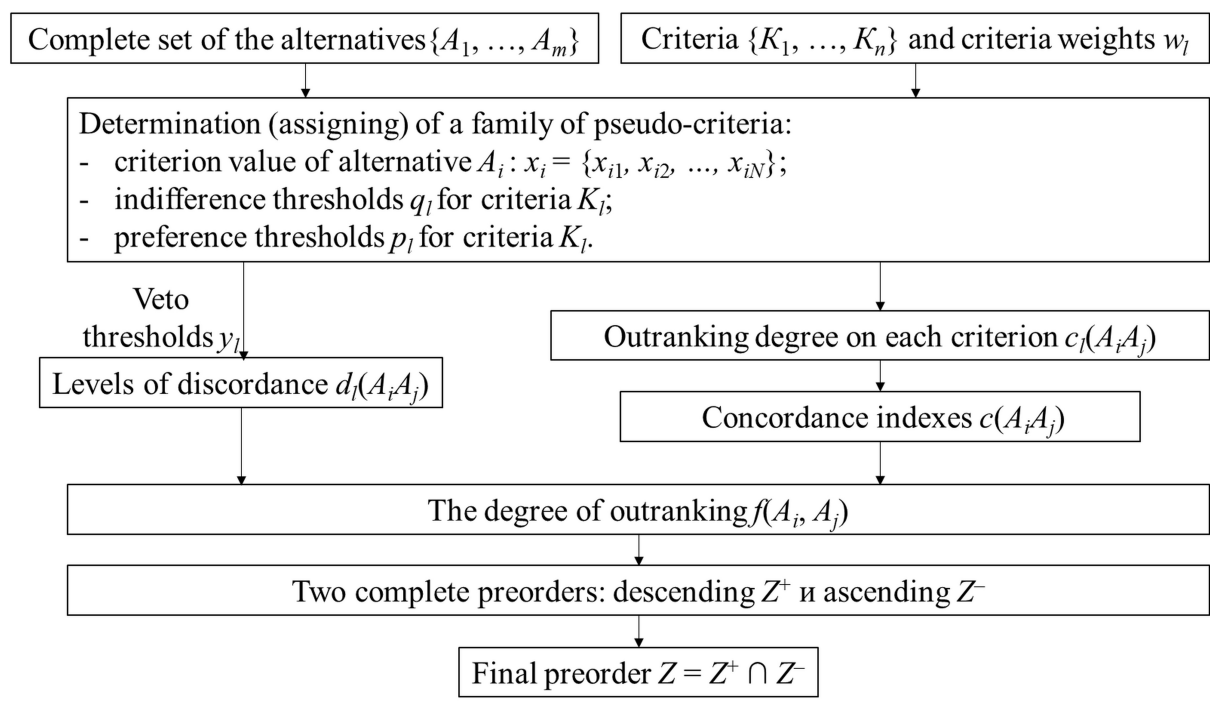

Fig. 1. General structure of ELECTRE III.

The initial data for decision making by ELECTRE III are [7]:

- complete set of alternatives $A=\left\{A_{1}, \ldots, A_{i}, \ldots, A_{j}, \ldots, A_{m}\right\}$;

- criteria $K=\left\{K_{1}, \ldots, K_{l}, \ldots, K_{n}\right\}$;

- $x_{i l}=K_{l}\left(A_{i}\right)$ - criterion value of alternative.

Thresholds and weights represent subjective input provided by the decision maker.

Consider two alternatives $A_{i}$ and $A_{j}$. They can be in the following relations:

- $A_{i} P_{(l)} A_{j}-A_{i}$ is strongly preferred to $A_{j}$ by criterion $K_{l}$, if $x_{i l}>x_{j l}+p_{l}\left(x_{j l}\right)$;

- $A_{i} Q_{(l)} A_{j}-A_{i}$ is weakly preferred to $A_{j}$ by criterion $K_{l}$, if $q_{l}\left(x_{j l}\right)<x_{i l}-x_{j l} \leq p_{l}\left(x_{j l}\right)$;

- $A_{i} I_{(l)} A_{j}-A_{i}$ is indifferent to $A_{j}$; and $A_{j}$ to $A_{i}$ by criterion $K_{l}$, if $x_{i l}-x_{j l} \leq q_{l}\left(x_{j l}\right)$.

This method and equations for determination of all indicators and ranking of alternatives are described in detail in [5-8]. 


\section{Results}

To solve the task of choosing geokhods cutterheads that more fully satisfying for requirements for them, with the ELECTRE III it is necessary to determine the alternatives and criteria. Different types of geokhod's cutterheads are alternatives [10] (fig. 2). There are cutting drum $\left(A_{1}\right)$, radial multi-heading $\left(A_{2}\right)$, rotating cutterhead $\left(A_{3}\right)$, single-heading $\left(A_{4}\right)$ and double-heading $\left(A_{5}\right)$ cutterheads.

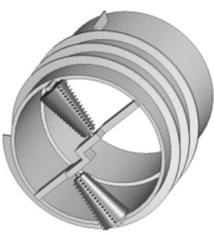

b)

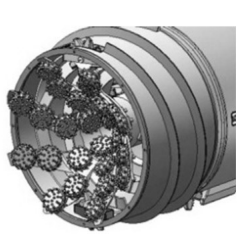

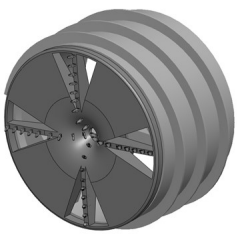

d)

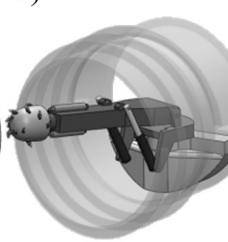

e)

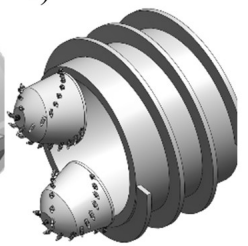

Fig. 2. Different types of geokhods cutterheads: a) - cutting drum, b) - radial multi-heading, c) rotating cutterhead, d) - single-heading, e) - double-heading.

As criteria are the requirements for geokhods cutterheads. With a large number of criteria it is necessary to combine them into larger groups that differ in meaning. For geokhods cutterheads the requirements combined into six generalized groups are given in table 4.

Table 4. The structure of the requirements for geokhod's cutterheads and range values of criteria.

\begin{tabular}{|c|c|c|c|}
\hline Meaning of group & $\begin{array}{l}\text { Generalized groups of } \\
\text { requirements (criteria) }\end{array}$ & $\begin{array}{l}\text { Range } \\
\text { values of } \\
\text { criteria }\end{array}$ & Single requirements \\
\hline \multirow{3}{*}{$\begin{array}{l}\text { Ensuring movement } \\
\text { possibility }\end{array}$} & \multirow{3}{*}{$\begin{array}{l}K_{1} \\
\text { Ensuring the continuous } \\
\text { movement of the } \\
\text { geokhod to the forehead } \\
\text { at a given speed }\end{array}$} & \multirow{3}{*}{$0-6$} & $\begin{array}{l}\text { Compliance of work of the } \\
\text { cutterheads to the number of } \\
\text { movement parameters of geokhod } \\
\text { to the forehead }\end{array}$ \\
\hline & & & $\begin{array}{c}\text { The destruction of the all surface } \\
\text { area of the forehead on the amount } \\
\text { of movement per revolution of } \\
\text { geokhod. }\end{array}$ \\
\hline & & & $\begin{array}{c}\text { Compliance of the geometrical } \\
\text { parameters of the cutterhead with } \\
\text { the parameters of the external } \\
\text { drive }\end{array}$ \\
\hline $\begin{array}{l}\text { Ensuring of changing } \\
\text { the direction of } \\
\text { movement possibility }\end{array}$ & $\begin{array}{l}K_{2} \\
\text { Ensuring of changing } \\
\text { the direction of } \\
\text { movement possibility } \\
\end{array}$ & $0-2$ & $\begin{array}{l}\text { The possibility of extension of the } \\
\text { cutterheads out of the geokhod's } \\
\text { body. }\end{array}$ \\
\hline \multirow{3}{*}{$\begin{array}{l}\text { Operational } \\
\text { requirements }\end{array}$} & \multirow{3}{*}{$\begin{array}{l}K_{3} \\
\text { High reliability of } \\
\text { cutterheads }\end{array}$} & \multirow{3}{*}{$0-6$} & Uniform load of the cutterhead \\
\hline & & & $\begin{array}{l}\text { The minimum dynamic of the } \\
\text { working }\end{array}$ \\
\hline & & & $\begin{array}{l}\text { Minimum number of the drives } \\
\text { and active elements }\end{array}$ \\
\hline
\end{tabular}




\begin{tabular}{|c|c|c|c|}
\hline & $\begin{array}{c}K_{4} \\
\text { Prevention of rockfall }\end{array}$ & $0-2$ & $\begin{array}{l}\text { Possibility to install a protective } \\
\text { membrane (diaphragm) }\end{array}$ \\
\hline & \multirow{2}{*}{$\begin{array}{l}K_{5} \\
\text { Possibility of } \\
\text { maintenance of the } \\
\text { drive and the rock } \\
\text { cutting tools }\end{array}$} & \multirow{2}{*}{$0-4$} & $\begin{array}{l}\text { Access to the cutterhead drives } \\
\text { and the possibility of replacing the } \\
\text { rock cutting tools }\end{array}$ \\
\hline & & & $\begin{array}{l}\text { Minimum mass and dimensional } \\
\text { characteristics of the cutterheads } \\
\text { and drives }\end{array}$ \\
\hline \multirow{5}{*}{$\begin{array}{l}\text { Energetical } \\
\text { requirements }\end{array}$} & \multirow{5}{*}{$\begin{array}{c}K_{6} \\
\text { Low specific energy }\end{array}$} & \multirow{5}{*}{$0-10$} & $\begin{array}{l}\text { Creation and destruction of the } \\
\text { ledge at the forehead }\end{array}$ \\
\hline & & & $\begin{array}{l}\text { Ability to control the orientation } \\
\text { of stresses in the rock mass }\end{array}$ \\
\hline & & & $\begin{array}{l}\text { Destruction of the ledge on the } \\
\text { free surface }\end{array}$ \\
\hline & & & Low dust intensity \\
\hline & & & $\begin{array}{l}\text { High drive efficiency of the } \\
\text { cutterhead }\end{array}$ \\
\hline
\end{tabular}

Using criteria to evaluate alternatives requires the definition of quality gradations, that is, the scale of evaluation criteria. The criterion scale may be natural or artificial. The natural scale is a property, objectively inherent to the object. The artificial scale is designed specifically to describe some important features of the object. At the initial stages of the analysis of different variants of cutterheads of geokhods for all criteria, artificial scales are designed, since the quantitative parameters have not yet been determined. Table 4 shows the ranges of scale values according to the generalized criteria from the condition that all single criteria can be equal to 0,1 or 2 .

For each of the alternatives are assigned the criteria values (Table 5), and each criterion is assigned a weight and threshold indicators (Table 6).

Table 5. Performance matrix.

\begin{tabular}{|c|c|c|c|c|c|c|}
\hline \multirow{2}{*}{ Alternatives } & \multicolumn{7}{|c|}{ Criteria } \\
\cline { 2 - 7 } & $K_{1}$ & $K_{2}$ & $K_{3}$ & $K_{4}$ & $K_{5}$ & $K_{6}$ \\
\hline$A_{1}$ & 6 & 2 & 5 & 2 & 4 & 10 \\
\hline$A_{2}$ & 6 & 1 & 4 & 2 & 2 & 6 \\
\hline$A_{3}$ & 6 & 1 & 6 & 2 & 1 & 4 \\
\hline$A_{4}$ & 3 & 2 & 5 & 0 & 2 & 10 \\
\hline$A_{5}$ & 5 & 2 & 3 & 2 & 3 & 10 \\
\hline
\end{tabular}

Table 6. Thresholds and weights.

\begin{tabular}{|c|c|c|c|c|c|c|}
\hline Threshold (weight) & $K_{1}$ & $K_{2}$ & $K_{3}$ & $K_{4}$ & $K_{5}$ & $K_{6}$ \\
\hline Criteria weight $w l$ & 0,25 & 0,25 & 0,1 & 0,15 & 0,15 & 0,1 \\
\hline Indifference thresholds $q_{l}$ & 1 & 0 & 1 & 0 & 1 & 1 \\
\hline Preference thresholds $p_{l}$ & 3 & 1 & 2 & 1 & 3 & 3 \\
\hline Veto thresholds $y_{l}$ & 6 & 2 & 3 & 2 & 4 & 4 \\
\hline
\end{tabular}

Tables 4, 5 and the alternatives (Fig. 2) are the initial data for ELECTRE III, and Table 6 - decision makers preferences. 
Without giving here the intermediate calculations of concordance and discordance indexes, levels of discordance, etc. for $e_{2}=0,2 f_{\max }$ in correspondence with the algorithm on Fig. 1 were got descending, ascending and final preorders:

$$
\begin{aligned}
Z^{+} & \Leftrightarrow A_{1} \succ\left(A_{3} \approx A_{5}\right) \succ\left(A_{2} \approx A_{4}\right), \\
Z^{-} & \Leftrightarrow\left(A_{1} \approx A_{5}\right) \succ A_{3} \succ\left(A_{2} \approx A_{4}\right), \\
Z & \Leftrightarrow A_{1} \succ A_{5} \succ A_{3} \succ\left(A_{2} \approx A_{4}\right) .
\end{aligned}
$$

The final preorder determines the ranking of alternatives:

1) cutting drum;

2) double-heading;

3) rotating cutterhead;

4) single-heading and multi-heading.

\section{Discussion}

At this stage, it is necessary not to choose the best alternative, and to exclude from further consideration the worst alternatives (single-heading and multi-heading), because the assigned criteria values to alternatives are subjective.

According to the results of the analysis, the cutterheads that the best satisfying for requirements for geokhods cutterheads are:

- cutting drum [12];

- double-heading;

- rotating cutterhead.

It is impossible to choose the best cutterhead without determining geometric, kinematic and power parameters its works as the geokhod's cutterhead for those alternatives.

The research was sponsored by Grant of the President of the Russian Federation for state support of young Russian scientists MK-664.2018.8.

\section{References}

1. V.Yu. Sadovets, V.Yu. Beglyakov, A.B. Efremenkov, Applied Mechanics and Materials, 770, 384 (2015)

2. V.V. Aksenov, A.B. Efremenkov, V. Yu. Sadovets, E.V. Resanova, Bulletin of KuzSTU, 1, 42 (2010)

3. A.V. Grigoryev, I.Y. Semykina, A.N. Ermakov, I.V. Chicherin, V.V. Aksenov, 19th International Conference of Young Specialists on Micro/Nanotechnologies and Electron Devices, 1, 667 (2018)

4. V.V. Aksenov, A.B. Efremenkov, V.Yu. Sadovets, M.Yu Blaschuk, V.Yu Timofeev, V.Yu Begljakov, Mining Informational and analytical Bulletin, 10, 107 (2009)

5. C. Zopounidis, P. M. Pardalos, Handbook of Multicriteria Analysis (DMIA, Berlin, 2010)

6. X. Sun, Vom Promotionsausschuss (Technischen Universitat Hamburg, Hamburg, 2012)

7. G.-H. Tzeng, J.-J. Huang, Multiple Attribute Decision Making: Methods and Applications (CDMS, Beijing, 2011)

8. A. Ishizaka, P. Nemery, Multi-criteria decision analysis: methods and software (Tollman Press, Manchester, 2013) 
9. H. Polatidis, D. A. Haralambopoulos, G. Munda, R. Vreeker, Energy Sources, 1:2, 181 (2006)

10. A.A. Khoreshok, V.V. Aksenov, K. A. Ananiev, A.N. Ermakov, News of the Higher Institutions. Mining Journal, 3, 73 (2014)

11. A.N. Ermakov, V.V. Aksenov, A.A. Khoreshok, K. A. Ananiev, Bulletin of KuzSTU, 2, 5 (2014)

12. A.A. Khoreshok, V.V. Aksenov, K. A. Ananiev, A.N. Ermakov, Proceedings of the 9th China-Russia Symposium "Coal in the 21st Century: Mining, Intelligent Equipment and Environment Protection", 176, 218 (2018) 